\title{
Fallopian Tube Cancer pT2a TNM Finding v7
}

National Cancer Institute

\section{Source}

National Cancer Institute. Fallopian Tube CancerpT2a TNM Finding v7. NCI Thesaurus. Code C89675.

Fallopian tube cancer with extension and/or metastasis to the uterus and/or ovaries.

(from AJCC 7th Ed.) 